\title{
Fish Health Assessment in Relation to Sex and Season: Haematolog- ical Variations and Serum Biochemical Constituents of Labeo robita (Hamilton, 1822) from Kotri Barrage near Jamshoro, Sindh, Pakistan
}

\author{
Saddar Faheem ${ }^{1,2}$, Hameeda Kalhoro ${ }^{1}$, Naeem Tariq Narejo ${ }^{1 *}$, Muhammad Hanif Chandio ${ }^{3}$, Memon \\ Samina $^{4}$, Shahnaz Rashid ${ }^{5}$ and Ghulam Abbas ${ }^{5 *}$
}

${ }^{1}$ Department of Fresh Water Biology and Fisheries, University of Sindh, Jamshoro, Sindh, Pakistan; ${ }^{2}$ Marine Fisheries Department, Government of Pakistan, West Wharf, Karachi, Pakistan; ${ }^{3}$ Directorate of Fisheries (Inland), Government of Sindh, Hyderabad, Pakistan; ${ }^{4}$ Directorate of Animal Breeding Department of Livestock and Fisheries, Hyderabad, Pakistan; ${ }^{5}$ Centre of Excellence in Marine Biology, University of Karachi, Karachi, Pakistan.

\begin{abstract}
This study was focused on fish health assessment in relation to sex and season via haematological variations and serum biochemical constituents of Labeo robita from Kotri Barrage near Jamshoro, Sindh, Pakistan. Fish samples (100 specimens for each sex) were collected during two seasons i.e., summer: March to May, 2017 and winter: November, 2017 to January, 2018. Haematological characteristics of the fish specimens were considered season and sex wise separately. Results showed that erythrocytes $\left(2.09 \times 10^{6}\right.$ to $\left.2.26 \times 10^{6}\right)$, leucocytes $\left(164.90 \times 10^{3}\right.$ to $\left.145.55 \times 10^{3}\right)$ and haemoglobin $(10.34 \mathrm{~g} / 100 \mathrm{ml}$ to $7.06 \mathrm{~g} / 100$ $\mathrm{ml}$ ) concentration were significantly higher in male fish during summer and winter than that of female. In female fish, erythrocyte sedimentation rate (ESR) in summer and winter season was found higher (7.3 $\mathrm{mm} / \mathrm{h}$ to $2.56 \mathrm{~mm} / \mathrm{h}$ ). Thrombocytes, neutrophils, lymphocytes, eosinophil and monocytes did not show any significant difference in their counts of male and female fish during summer and winter season. Important serum constituents like protein, cholesterol and glucose were also assessed and it was reported that serum glucose was found more in male than female fish, while in male protein and cholesterol were high in female in summer. In winter season, female fish showed low level of cholesterol, though protein and glucose remained high. Based on the serum biochemical constituent data, it was concluded that male L. rohita were healthier than the female fish in terms of blood parameters.

Received | May 23, 2021; Accepted | June 13, 2021; Published | July 15, 2021

*Correspondence | Ghulam Abbas and Naeem Tariq Narejo, Centre of Excellence in Marine Biology, University of Karachi, Karachi-75270, Pakistan; Department of Fresh Water Biology and Fisheries, University of Sindh, Jamshoro Pakistan; Email: ghulamabbas@uok.edu.pk; naeem. tariq@usindh.edu.pk

Citation | Faheem, S., H. Kalhoro, N.T. Narejo, M.H. Chandio, M. Samina, S. Rashid and G. Abbas. 2021. Fish health assessment in relation to sex and season: haematological variations and serum biochemical constituents of Labeo robita (Hamilton, 1822) from Kotri Barrage near Jamshoro, Sindh, Pakistan. Sarhad Journal of Agriculture, 37(3): 1043-1049.

DOI | https://dx.doi.org/10.17582/journal.sja/2021/37.3.1043.1049

Keywords | Labeo rohita, Haematology, Serum analysis, Kotri Barrage, Seasonal variation
\end{abstract}

\section{Introduction}

$\mathrm{F}$ ish imitate to situation of water quality and pollution since they existed at the lowest level of food chain of aquatic bodies. They can obtain and retain chemicals like heavy metals and pesticides through submissive phenomena so pollutant in their environment can be identified. Fish consume greater amount of algae, phytoplankton and different aquatic plant infected with pesticide, which consequently 
lead these chemicals to gradually accumulate in tissues and organs of fish. Metabolism can regulate little amount of these chemicals while remaining one get bio-accumulated in the organs and organs system of fish. Humen living near water bodies use water for decontamination and waste removal of society. Biological and physical processes affecting water quality cause water pollution leading to deleterious influences on health and composition of aquatic sources (Ambreen and Javed, 2018; Tahir et al., 2021). Enhanced amount of toxic substances and pollutants in fresh water have threatened numerous freshwater flora and fauna including fish. Likewise, it is detrimental for human health causing disorders and fourteen thousand deaths on daily basis (Reddy and Behera, 2006). Direct emission of domestic and industrial wastes into water bodies without any processing leads to water contamination. Various pollutants like heavy metals, pesticides, herbicides, radioactive matter and corrosive material are causing pollution of water bodies. Change in the physicochemical parameters of aquatic sources influence the metabolism and homeostasis of aquatic life and disturbance in food web consequently (Pisa et al., 2015; Tahir et al., 2021).

Haematological and serological parameters are significant for measurement of pathophysiological condition of fish. These parameters extensively used as indicators of infection or stress caused by contaminants because haematological profile exhibit the internal body situation before any prominent disease identification (Ali and Rani, 2009). Gills, skin or alimentary canal mainly absorbs different pollutants so they can diffuse into other organs and tissues ultimately affecting physiological and natural phenomena of fish (Banaee et al., 2008; Tahir et al., 2021). Gills are the most affected organs due to pollutants as these are entirely exposed organs to water. Entrance of toxicants in body is done through gills so consumption of oxygen increases. As a result, it is significant parameter to observe any toxic stress in aquatic environment (Panigrahi et al., 2014). Accumulation of surplus constituents into the aquatic sources may cause alterations in the physicochemical and biological features leading to the ecological disparity (Yadav et al., 2018a). Effluents containing pesticide and heavy metals contributed greatly to water pollution creating threat for aquatic life (Gbemi and Bemigho, 2009; Denson et al., 2003; Jenikins et al., 2003; Gupta and Mishra, 2012; Yadav et al., 2018b;
Tahir et al., 2021). Occurrence of pesticides in water bodies caused by various ways but three important routes were assessed owing to which it found its significant way to aquatic systems (Kosygin et al. 2007; Sarkar et al., 2008; Tahir et al., 2021). These significant paths include water pathways, organic substrates like vascular hydrophytes, branches, mosses, algae, leaf litter and inorganic substrates comprising materials from sediments with different sizes (Murthy et al., 2013; Tahir et al., 2021).

It is well known that haematological and serum biochemical changes are termed as pre-requisite to determine the health status of fish before and after stocking (Ghaffar et al., 2018, 2019). These changes may be due to seasonal stress, food deficiency and certain environmental factors that directly or indirectly affect the well-being of the fish (Narejo et al., 2001; Ghaffar et al., 2015a, 2016, 2018, 2019). The blood factors like counts of red and white cells, content of haemoglobin, rate of sedimentation of red cells and haematocrit could be deviated in sexes, duration of life and certain water factors (Ezzat et al., 1974; Fernandes, 2003; Kohanestani et al., 2013; Ghaffar et al., 2015b, 2018). The fish Labeo rohita locally known as (Rahu) from the cyprinidae family and order cypriniformes is usually found in variety of sweet water environments of this sub-continent (Rahman 1989; Ghaffar et al., 2015b, 2018). It is very tasty and extensively recognized fish of the area despite this no commencement to explore for determining its haematological and serum investigations from Kotri Barrage, Sindh, Pakistan. This fish has been prized for culturing in ponds on extensive scale.

Few isolated reports on its haematology are available from elsewhere Bangladesh and India (Narejo et al., 2001). The present investigation was initiated to furnish some information regarding abundance and health status of this economically important fish, Labeo rohita that will be helpful for enhancing annual production in Kotri Barrage in summer and winter seasons, keeping in view that blood parameters play important role in understanding physiology of the fish (Ghaffar et al., 2018, 2019).

\section{Materials and Methods}

\section{Collection and preservation of blood}

Blood samples were collected monthly during summer (March to May, 2017) and winter (November, 2017 
to January, 2018) from 100 specimens for each sex, having size ranged between 28.0 to $38.0 \mathrm{~cm}$ and 400 to $510 \mathrm{~g}$ from Kotri Barrage near Jamshoro, Sindh. The blood was obtained by piercing fish caudal vein by using pasteurized disposable syringe. Subsequently, blood was moved to a vial comprising an anticoagulant of $3.60 \%$ sodium citrate (EDTA). For serum analysis, the blood stored without EDTA containing tubes for allowing the clot blood and separated serum by centrifuge machine at $350 \mathrm{rpm}$ in the lab.

\section{Determination of haematological factors}

For blood cell studies, the area of caudal fin was sterilized with swab of alcohol (70 \%) to save from the contamination the pricking of needle was soaked with prior to collection of blood and also soaks the area of pricking of needle with alcohol (70\%) swab. The neubauer's double haemocytometer was used with Shaw's fluids to determine counts of red and white blood cells. The Packed Cell Volume (PCV) and ESR were determined according to the methods suggested by Barnhart (1969). The blood sample tube was put in an extraordinary shelf in upright position for one hour and the ESR was explained through the estimation of distance which erythrocytes had residues from top of the tube and the outcome was communicated in $\mathrm{mm} / \mathrm{h}$. The blood sample tube was then rotated in haematocrit rotator at $3000 \mathrm{rpm}$ for thirty minutes (Siddiqui and Naseem, 1979; Ghaffar et al., 2018). The hemoglobin percentage in blood was assessed by using Sahli's haemocytomete. The erythrocyte counts, hemoglobin fixation and haematocrit values were determined as indicated by Daice and Lewis (1977). Differential cell checks were produced using the slight blood films arranged on glass slides following assortment of the blood tests, which were air dried, stained with Wright and Giemsa stain (Chinabut et al., 1991), washed in running faucet water and dried followed by mounting in Canada amber. The stained blood smears were subsequently examined by using microscope. An aggregate of 100 leucocytes were included under haematological varieties in $L$. robita magnifying instrument at $\times 45$ for each example and the rates of various kinds of leucocytes were properly determined.

\section{Analysis of serum constituents}

Blood serum biochemical constituents like glucose, protein and cholesterol were carried out through the recommended methods (Fawcette and Scott, 1960; Henry, 1968; Annino, 1976; Ghaffar et al., 2015a, b, 2018, 2019). The analysis was done at PCSIR Laboratories Complex Karachi.

\section{Results and Discussion}

Hematological research of fish has gained great significance because these factors were used as an effective and sensitive index for evaluation of physiological and pathological alteration caused by contamination of aquatic sources. Hematological parameters therefore considered as important tool for identifying performance status of an animal (Ali and Rani, 2009). Pesticides usually made relatively rapid alterations in hematological parameters of fish (Pisa et al., 2015; Rezania et al., 2018; Tahir et al., 2021). Therefore, haematologic index may be used efficiently for observing the health and retort of fish and aquatic organisms to different toxic constituents exhibiting environmental position of the territory (Pimpao et al., 2007). Rios et al. (2002) studied that blood parameters in fish got affected by features like gender, oldness, mass, propagative stage, health, seasonal dynamics, water temperature, feature of environmental, nutrition and stress (Hrubec et al., 2008).

In the present study, haematological parameters were investigated to assess the health of the fish collected from Kotri barrage, Sindh. All haematological parameters were found to be in normal range. Table 1 gives significantly different haematological limits and serum examination of male $(\mathrm{M})$ and female $(\mathrm{F})$ L. rohita. The leucocytes (M: $\left.164.90 \pm 69.91 \times 10^{3}\right)(\mathrm{F}$ : $\left.154.38 \pm 15.43 \times 10^{3}\right)$, erythrocytes (M: $2.37 \pm 0.12 \times 10^{6}$ ) (F: $\left.1.38 \pm 0.05 \times 10^{6}\right)$, haemoglobin level $(\mathrm{M}: 10.3 \pm 4.50$ $\mathrm{g} / 100 \mathrm{ml})(\mathrm{F}: 7.7 \pm 1.05 \mathrm{~g} / 100 \mathrm{ml})$ and $\operatorname{ESR}(\mathrm{M}$ : $1.3 \pm 3.0 \mathrm{~mm} / \mathrm{h})(\mathrm{F}: 7.1 \pm 5.36 \mathrm{~mm} / \mathrm{h})$ showed that male specimens of the fish exhibited high counts of erythrocytes, leucocytes and hemoglobin as compared to those of the female fish in summer season. In addition, female L. rohita were had higher ESRs in summer days. Furthermore, It was also noted that the concentration of glucose in serum was higher in male specimens than females during summer season.

The variation of these factors during winter was found to be non-significant among the sexes and as well as in serum analysis of L. rohita from Kotri Barrage, near Jamshoro (Table 2).

The blood smears showed that fishes remained healthy in summer and winter season as the nuclei in 
the blood cells were found in central position (Figures 1 and 2).

Table 1: Total length, total weight, and haematological profile comprising serum biochemical constituents of male and female Labeo robita during summer season from Kotri Barrage near Jamshoro, Sindh.

$\begin{array}{lll}\text { Parameters } & \text { Male } \text { L. rohita } & \text { Female } \text { L. rohita } \\ \text { Total length }(\mathrm{cm}) & 31.13 \pm 2.59 & 36 . \pm 11.27 \\ \text { Total weight }(\mathrm{gm}) & 450 \pm 1.04 & 490 \pm 1.02 \\ \mathrm{Hb}(\mathrm{g} / 100 \mathrm{ml}) & 10.34 \pm 4.50 & 7.68 \pm 1.05 \\ \text { ESR }(\mathrm{mm} / \mathrm{h}) & 1.31 \pm 3.0 & 7.13 \pm 5.35 \\ \text { TEC }\left(\mathrm{x} 10^{6}\right) & 2.37 \pm 0.12 & 1.38 \pm 0.05 \\ \text { TLC }\left(\mathrm{x} 10^{3}\right) & 164.90 \pm 69.91 & 154.38 \pm 15.43 \\ \text { PCV \% } & 24.07 \pm 7.97 & 21.78 \pm 2.59 \\ \text { MCV }(\mu \mathrm{m}) & 123.29 \pm 28.47 & 121 \pm 28.47 \\ \text { MCHC \% } & 40.73 \pm 20.99 & 45.23 \pm 8.32 \\ \text { Differential count \% } & & \\ \text { Thrombocytes } & 29.10 \pm 10.90 & 30.20 \pm 4.80 \\ \text { Neutrophils } & 2.00 \pm 0.50 & 1.50 \pm 0.50 \\ \text { Lymphocytes } & 66.20 \pm 8.80 & 65.50 \pm 8.50 \\ \text { Eosinophil } & 1.50 \pm 0.50 & 1.55 \pm 0.45 \\ \text { Monocytes } & 1.20 \pm 0.60 & 1.25 \pm 0.75 \\ \text { Serum analysis } & & \\ \text { Glucose mg/dl } & 205.15 \pm 0.85 & 203.85 \pm 0.15 \\ \text { Protein mg/dl } & 10.47 \pm 0.53 & 10.74 \pm 0.26 \\ \text { Cholesterol mg/dl } & 126.50 \pm 1.50 & 125.35 \pm 0.65\end{array}$

Values are the mean of four samples with standard deviation $\pm S D$.

Table 2: Total length, total weight, and haematological profile comprising serum biochemical constituents of male and female Labeo robita during winter season from Kotri Barrage near Jamshoro, Sindh.

$\begin{array}{lcl}\text { Parameters } & \text { Male } \text { L. rohita } & \text { Female } \text { L. rohita } \\ \text { Total length }(\mathrm{cm}) & 35.5 \pm 2.50 & 39.3 \pm 1.70 \\ \text { Total weight }(\mathrm{gm}) & 500.0 \pm 10.0 & 560.8 \pm 20.20 \\ \mathrm{Hb}(\mathrm{g} / 100 \mathrm{ml}) & 7.07 \pm 1.62 & 6.82 \pm 1.34 \\ \mathrm{ESR}(\mathrm{mm} / \mathrm{h}) & 2.27 \pm 0.13 & 2.56 \pm 0.68 \\ \mathrm{TEC}\left(\mathrm{x} 10^{6}\right) & 1.39 \pm 0.11 & 1.29 \pm 0.31 \\ \text { TLC }\left(\mathrm{x} 0^{3}\right) & 148.5 \pm 18.9 & 140.4 \pm 16.51 \\ \mathrm{PCV} \% & 23.5 \pm 7.97 & 22.8 \pm 2.59 \\ \mathrm{MCV}(\mu \mathrm{m}) & 120.4 \pm 28.47 & 122.6 \pm 28.47 \\ \text { MCHC \% } & 41.2 \pm 20.99 & 44.6 \pm 8.32 \\ \text { Differential count \% } & & \\ \text { Thrombocytes } & 29.90 \pm 1.20 & 30.2 \pm 2.80 \\ \text { Neutrophils } & 1.5 \pm 0.50 & 1.5 \pm 0.45 \\ \text { Lymphocytes } & 65.80 \pm 11.20 & 65.50 \pm 10.70 \\ \text { Eosinophil's } & 1.5 \pm 0.50 & 1.5 \pm 0.50 \\ \text { Monocytes } & 1.30 \pm 0.70 & 1.3 \pm 0.5 \\ \text { Serum analysis } & & \\ \text { Glucose } \mathrm{mg} / \mathrm{dl} & 201.20 \pm 0.80 & 202.40 \pm 0.60 \\ \text { Protein mg/dl } & 9.45 \pm 0.55 & 9.90 \pm 0.10 \\ \text { Cholesterol mg/dl } & 127.40 \pm 0.60 & 126.60 \pm 0.40\end{array}$

Values are the mean of four samples with standard deviation $\pm S D$.

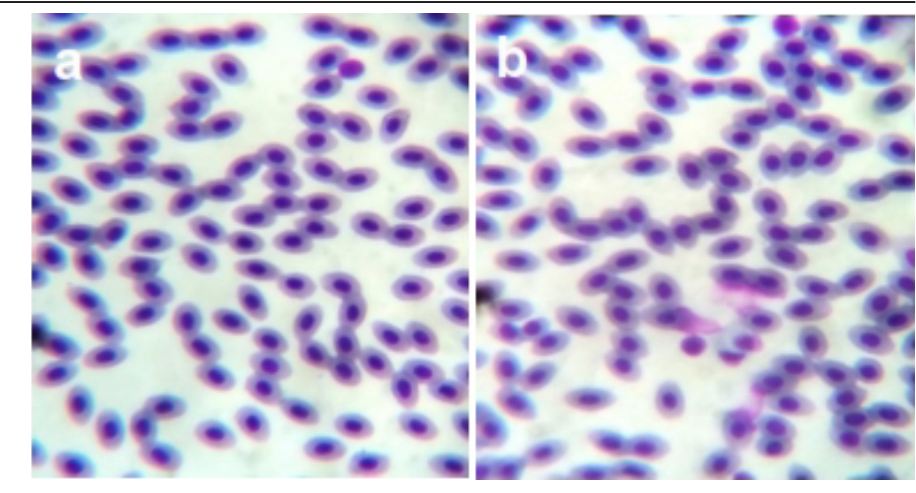

Figure 1: Photomicrograph of normal blood smear of male (a) and female (b) Labeo rohita during summer season from Kotri Barrage near Jamshoro, Sindh.

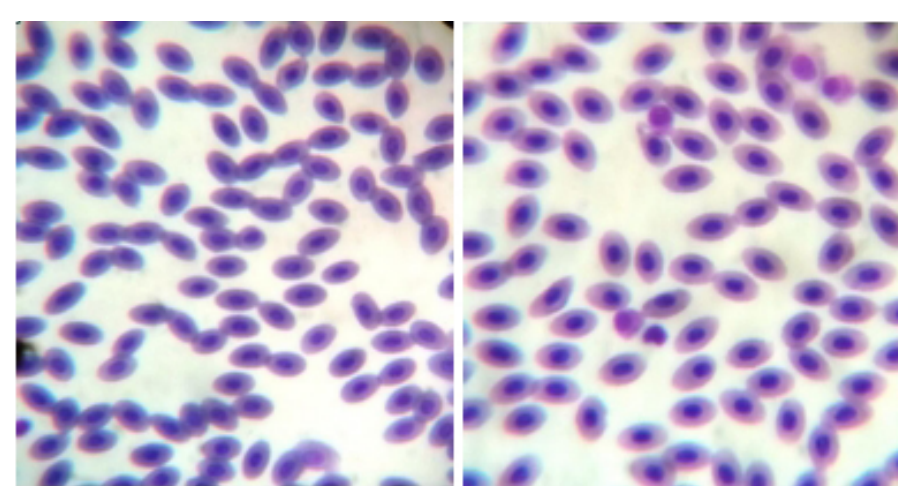

Figure 2: Photomicrograph of normal blood smear of male (a) and female (b) Labeo robita during winter season from Kotri Barrage near Jamshoro, Sindh.

Similar observations have been reported by Narejo et al. (2002) from Bangladesh in $M$. armatus and commented that the erythrocytes, concentration of haemoglobin, haematocrit, packed cell volume (PCV) and neutrophil counts were found to be high in males in contrast to female in the months of summer up to breeding season and females have significantly higher values in (ESR), (TLC) and thrombocyte count during summer. In winter the non-significant variation observed between the two sexes. Siddique and Naseem (1979) and Ghaffar et al. (2018) while working on hematology of the same fish Rahu declared that male had high values of in that of female due to development of gonads. Gupta and Mishra (2012) analyzed deviation of blood factors during different seasons in Clarias gariepinus. Haematological indices revealed that deviation was observed in the counts of red blood cells, MCV and MCHC factors in various seasons. Kori et al. (2009) recorded haematological analysis in Clarias gariepinus raised in dissimilar concentrations of potassium permanganate and noted the values of red blood cell count low in high concentration of potassium permanganate. Mohan and Dhanapalan (2015) published review on calculation blood factors 
and biochemical indices of serum in three fish species from Cauvery River. Shakoori et al. (1996) reported health aspects of herbivore, omnivore and carnivore fishes on the basis of food habit. According to Narejo et al. (2001), the ratio between RBCs and WBCs was significantly high due to reduced levels of WBC throughout this research. Such variances may be credited to the physical adaptation of fishes to their living circumstance and nourishing protocol, which affects the energy breakdown and subsequently affects fish health. Serum biochemical constituents are generally used for checking fish maturity stages and observing any significant alterations in water quality and connected soil environmental parameters. The findings of the above authors accords with the present investigations.

\section{Conclusions and Recommendations}

It was found that that serum glucose concentration was significantly high in male fish than female one. Erythrocytes, leucocytes and hemoglobin concentrations remained high in male fish, Labeo robita during summer season. However, females showed high counts of ESR in summer season. Although, it was also noted.

\section{Acknowledgements}

This research is a part of the $\mathrm{Ph} . \mathrm{D}$ thesis of first author (Saddar Faheem). He wishes to thank Prof. Dr. Naeem Tariq Narejo, Chairman Fresh Water Biology and Fisheries, University of Sindh for providing lab. facilities.

\section{Novelty Statement}

The discoveries of this examination will be productive in the headway of business fish cultivates in Sindh territory through the evaluation of fish serum quality especially in the mid-year and winter period. The blood plasma analysis showed that glucose concentration remained high in male individuals in summer days than female individuals though female fishes exhibited high level of protein and cholesterol. In winter season, cholesterol remained low and glucose along with protein was found to be high in female individuals than male. It was inferred that male fish discovered to be better as far as hematological limits than female of Labeo rohita from Kotri Barrage close to Jamshoro, Sindh.

\section{Author's Contribution}

Saddar Faheem: Collected fish and serum samples from sampling site, analysed them in the laboratory, organized and managed the research for his $\mathrm{Ph}$. D thesis.

Hameeda Kalhoro and Naeem Tariq Narejo: Supervised this research, searched relevant literature and helped in manuscript preparation.

Muhammad Hanif Chandio and Ghulam Abbas: Searched literature, manuscript reviewed, composed the document with data acquisition.

Memon Samina: Conducted blood serum biochemical analysis of the sampled fishes.

Shahnaz Rashid: Helped in composing, formatting and updating bibliography.

\section{Conflict of interest}

The authors have declared no conflict of interest.

\section{References}

Ali, H.A. and V.J. Rani. 2009. Effect of phosalone on haematological indices in the tilapia, Oreochromis mossambicus. Turk. J. Vet. Anim. Sci., 33: 407-411.

Ambreen, F. and M. Javed. 2018. Pesticide mixture induced DNA damage in peripheral blood erythrocytes of freshwater fish, Oreochromis niloticus. Pak. J. Zool., 50: 339-346. https://doi. org/10.17582/journal.pjz/2018.50.1.339.346

Annino, J.S. 1976. Clinical chemistry principles and procedures. $4^{\text {th }}$ edn. Little Brown and Company, Boston.

Banaee, M., A.R. Mirvaghefi, K. Ahmadi and S. Banaee. 2008. Determination of LC50 and investigation of acute toxicity effects of diazinon on hematology and serology indices of common carp (Cyprinus carpio). J. Mar. Sci. Tech. Res., 3: 1-10.

Barnhart, R.A. 1969. Effects of certain variables on haematological characteristics of rainbow trout Salmo gairdneri (R.). Trans. Am. Fish. Soc., 98: 417-418. https://doi.org/10.1577/15488659(1969)98[411:EOCVOH]2.0.CO;2

Chinabut, S., C. Limsuwan and P. Kitsawat. 1991. Histology of the walking catfish Clarias batrachus. Asian Fish Health Network Coordination Sponsored by International Development Research Center, Canada. pp. 94. Daice. J.V. and S.M. Lewis. 1977. Practical 
haematology. ELBS and Churchill, Livingstone. pp. 87.

Denson,M.R., K.R.Stuart,T.I.Smith,C.R.Weirlch and A.Segars.2003. Effects of salinity on growth, survival, and selected hematological parameters of juvenile cobia Rachycentron canadum. J. World Aquacult. Soc., 34(4): 496-504. https:// doi.org/10.1111/j.1749-7345.2003.tb00088.x

Ezzat, A.A., M.G. Shahan and A.M. Farhal. 1974. Studies on blood characteristics of Tilapia zillii (Gervais). 1. Blood cells. J. Fish Biol., 6: 1-12. https://doi.org/10.1111/j.1095-8649.1974. tb04516.x

Fawcette,J.K. and J.E. Scott.1960. Practical clinical biochemistry, $4^{\text {th }}$ edn. Arnold Harold Varley, pp. 119-122.

Fernandes, M.N. 2003. Environmental pollution and fish gill morphology. Fish Adapt., pp. 203231.

Gbemi, M. and R. Bemigho. 2009. Haematological response of the African catfish: Clarias gariepinus (Burchell, 1822) to sublethal concentrations of potassium permanganate. Sci. Res. Ess., 4(5): 457-466.

Ghaffar, A., R. Hussain, A. Khan, R.Z. Abbas and M. Asad. 2015a. Butachlor induced clinic hematological and cellular changes in fresh water fish Labeo robita (Rohu). Pak. Vet. J., 35: 201-206.

Ghaffar, A., R. Hussain, A. Khan and R.Z. Abbas. 2015b. Hemato-biochemical and genetic damage caused by triazophos in fresh water fish, Labeo rohita. Int. J. Agric. Biol., 17: 637-642. https://doi.org/10.17957/IJAB/17.3.14.1016

Ghaffar, A., R. Hussain, G. Abbas, K. Akram, H. Latif and A. Khan. 2019. Assessment of genotoxic and pathologic potentials of fipronil insecticide in Labeo rohita (Hamilton, 1822). Toxin Reviews, pp. 1-12. https://doi.org/10.10 80/15569543.2019.1684321

Ghaffar, A., R. Hussain, G. Abbas, M. Kalim, A. Khan, S. Ferrando, L. Gallus and Z. Ahmed. 2018. Fipronil (Phenylpyrazole) induces hemato-biochemical, histological and genetic damage at low doses in common carp, Cyprinus carpio (Linnaeus, 1758). Ecotoxicology, 27: 1261-1271. https://doi.org/10.1007/s10646018-1979-4

Ghaffar, A., R. Hussain, M. Aslam, G. Abbas and A. Khan.2016. Arsenic and urea in combination alters the hematology, biochemistry and protoplasm in exposed rohu fish (Labeo rohita) (Hamilton, 1822). Turk. J. Fish. Aquac. Sci., 16: 289-296. https://doi.org/10.4194/13032712-v16_2_09

Gupta, S. and P. Mishra. 2012. Haematological variation in cat fish. Asian J. Anim. Sci., 7(1): 19-22.

Henry, R.J. 1968. Clinical chemistry, principles and techniques. Harper and Row, New York, pp. 664-666.

Hrubec, T.C., S.A. Smith and J.L. Robertson. 2008. Age related differences in haematologic and plasma chemistry analyses of hybrid striped bass Morore chrysops x Morore saxatilis. Vet. Clin. Path., 30: 8-15. https://doi.org/10.1111/ j.1939-165X.2001.tb00249.x

Jenkins, F., J. Smith, B. Rajanna, U. Shameem, K. Umadevi, V. Sandhya and R. Mahadevi. 2003. Effect of sublethal concentration of endosulfan on haematological and serum biochemical parameters in the carp Cyprinus carpio. Bull. Environ. Cont. Tox., 70: 993-997. https://doi. org/10.1007/s00128-003-0080-7

Kohanestani,Z.M., A. Hajimoradloo, R. Ghorbani, S. Yulghi, A. Hoseini and M. Molaee. 2013. Seasonal variations in hematological parameters of Alburnoides eichwaldii in Zaringol StreamGolestan Province, Iran. World J. Fish Mar. Sci., 5(2): 121-126.

Kori, S., O. Ogbe, M. Gbemi and I.B. Robert. 2009. Haematological response of the African catfish: Clarias gariepinus (Burchell, 1822) to sublethal concentrations of potassium permanganate. Sci. Res. Ess., 4(5): 457-466.

Kosygin, L., H. Dhamendra and R. Gyaneshwari. 2007. Pollution status and conservation strategies of Moirang river, Manipur with a note on its aquatic bio-resources. J. Environ. Biol., 28: 669-673.

Mohan, A. and S. Dhanapalan. 2015. Assessment of the haematological and serum biochemical parameters of three commercially important freshwater fishes in river Cauvery Velur, Namakkal district, Tamil Nadu, India. Int. J. Fish. Aquac. Stud., 4(1): 155-159.

Murthy, K.S., B.R. Kiran and M. Venkateshwarlu. 2013. A review on toxicity of pesticides in Fish. Int. J. Open Sci. Res., 1: 15-36.

Narejo, N.T., M.M. Rashid and S.M. Rahmatullah. 2001. Variations in the haematological parameters of the freshwater mud eel, 
Monopterus cuchia (Hamilton) with respect to sex and season. Bangladesh Vet., 18(1): 49-57.

Narejo, N.T., M.M. Rashid and S.M. Rahmatullah. 2002. Seasonal and sex related haematological variations of the freshwater spiny eel, Mastacembelus armatus (Lacepede) reared in the cemented cistern. Bangladesh J. Fish. Res., 6(2): 141-147.

Panigrahi, A.K., N. Choudhury and J. Tarafdar. 2014. Pollutional impact of some selective agricultural pesticides on fish Cyprinus carpio. IMPACT: Int. J. Res. Appl. Nat. Soc. Sci., 2: 71-76.

Pimpao, C.T., A.R. Zampronio, H.S. De Assis. 2007. Effects of deltamethrin on hematological parameters and enzymatic activity in Ancistrus multispinis (Pisces, Teleostei). Pest. Biochem. Phys., 88: 122-127. https://doi.org/10.1016/j. pestbp.2006.10.002

Pisa, L.W., V. Amaral-Rogers, L.P. Belzunces, J.M. Bonmatin, C.A. Downs, D. Goulson, D.P. Kreutzweiser, C. Krupke, M. Liess, M. McField and C.A. Morrissey. 2015. Effects of neonicotinoids and fipronil on non-target invertebrates. Environ. Sci. Poll. Res., 22: 68102. https://doi.org/10.1007/s11356-0143471-x

Rahman, A.K.A. 1989. Freshwater fishes of bangladesh. zoological society of Bangladesh, University of Dhaka, Bangladesh, pp. 264.

Reddy, V.R. and B. Behera. 2006. Impact of water pollution on rural communities: An economic analysis. Ecol. Econ., 58: 520-537. https://doi. org/10.1016/j.ecolecon.2005.07.025

Rezania, S., J. Park, M.F. Din, S.M. Taib, A. Talaiekhozani, K.K. Yadav and H. Kamyab. 2018. Microplastics pollution in differentaquatic environments and biota: A review of recent studies. Mar. Poll. Bull., 133: 191-208. https:// doi.org/10.1016/j.marpolbul.2018.05.022

Rios, F.S., A.L. Kalinin and F.T. Rantin. 2002. The effects of long-term food deprivation on respiration and haematology of the neotropical fish Hoplias malabaricus. J. Fish Biol., 61: 85-95. https://doi.org/10.1111/j.1095-8649.2002. tb01738.x

Sarkar, S.K., B.D. Bhattacharya, A. Bhattacharya, M. Chatterjee, A. Alam, K.K. Satpathy and M.P. Jonathan. 2008. Occurrence, distribution and possible sources of organochlorine pesticide residues in tropical coastal environmentofIndia: An overview. Environ. Int., 34: 1062-1071. https://doi.org/10.1016/j.envint.2008.02.010

Shakoori, A.R., A.L. Mughal, and M.J. Iqbal. 1996. Effects of sublethal doses of fenvalerate (a synthetic pyrethroid) administered continuously for four weeks on the blood, liver and muscles of a freshwater fish, Ctenopharyngodon idella. Bull. Environ. Contam. Toxicol., 57: 487-494. https://doi.org/10.1007/s001289900216

Siddiqui, A.Q. and S.M. Naseem. 1979. The haematology of Rohu, Labeo robita. J. Fish Biol., 14: 67-72. https://doi. org/10.1111/j.1095-8649.1979.tb03496.x

Tahir, R., A. Ghaffar, G. Abbas, T.H. Turabi, S. Kausar, X. Du, S. Naz, H. Jamil, Samra, S. Riaz and S.S. Abdelgayed. 2021. Pesticide induced hematological, biochemical and genotoxic changes in fish: A Review. Agrobiol. Rec., 3: 41-57.

Yadav, K.K., N. Gupta, V. Kumar, P. Choudhary and S.A. Khan. 2018a. GIS-based evaluation of groundwater geochemistry and statistical determination of the fate of contaminants in shallow aquifers from different functional areas of Agra city, India: levels and spatial distributions. RSC Adv., 8: 15876-15889. https://doi.org/10.1039/C8RA00577J

Yadav, K.K., N. Gupta, V. Kumar, S.A. Khan and A. Kumar. 2018b. A review of emerging adsorbents and current demand for defluoridation of water: bright future in water sustainability. Environ. Int., 111: 80-108. https://doi.org/10.1016/j. envint.2017.11.014 